\title{
STRENGTHENING STUDENTS' CHARACTER THROUGH MULTIMEDIA LEARNING IN PRIMARY SCHOOLS EDUCATION: SYSTEMATIC LITERATURE REVIEWS
}

\author{
Giri Prasetyo $^{1^{*}}$, M. F. Hidayatullah ${ }^{2}$, M. Akhyar ${ }^{3}$, Wiranto $^{4}$, Ryzal Perdana $^{5}$ \\ ${ }^{1,5}$ Student of Postgraduate Program, FKIP Universitas Sebelas Maret, Indonesia; ${ }^{2,3,4}$ Lecturers, Universitas Sebelas \\ Maret, Jl. Ir. Sutami 36A, Kentingan, Surakarta, Indonesia. \\ Email: ${ }^{1 *}$ giripras46@gmail.com, ${ }^{2}$ furqon@ fkip.uns.ac.id, ${ }^{3}$ muhammadakhyar@ staff.uns.ac.id, \\ ${ }^{4}$ wiranto@staff.uns.ac.id, ${ }^{5}$ ryzalperdana2009@gmail.com
}

Article History: Received on $24^{\text {th }}$ March 2020, Revised on $24^{\text {th }}$ April 2020, Published on $16^{\text {th }}$ May 2020

\begin{abstract}
Purpose of the study: The purpose of this review is to determine the extent to which the effective use of multi-media in strengthening character education to help students understand the character values contained in the subject matter.
\end{abstract}

Methodology: The method used is a literature review of the results of previous studies, which are related to improving character education in schools. The components of the literature review that became the center of attention include a) multi-media development, b) strengthening character education, c) and the relationship between multi-media development and strengthening character education.

Main Findings: The findings indicate that effective multi-media reinforcement of character education is significantly assisting students in comprehending the implicit learning goals included in the lessons taught in terms of values by character building.

Application of this study: The implication is to develop multi-media strengthening character education (KDP) in elementary schools will be able to form individuals who have the character to be a golden generation of Indonesia in 2045 with 21 st-century skills.

Novelty/Originality of this study: Multimedia development is used so that character learning in the world of education can run effectively. The development of multi-media reinforcement of character education (PPK) requires synergy between teacher understanding, school infrastructure, and student participation in receiving learning material.

Keywords: Multimedia, Reinforcement of Character Education, Character Building, Elementary School, Golden Generation, Students' Development.

\section{INTRODUCTION}

Education as one area of human life has an important role in creating a generation of people who are intelligent, wise, and have character. This is in line with the understanding of education following Law Number 20 the Year 2003 article 1 paragraph 1, namely education is a conscious and planned effort to create an atmosphere of learning and learning process so that students actively develop their potential to have religious-spiritual strength, self-control, personality, intelligence, noble character, and skills needed by himself, society, nation, and country. Character education is in line with thinking to create moral education.

The challenge of education to produce quality and resilient human resources is getting heavier. Education is not enough to stop at providing the most up-to-date knowledge, but also must be able to form and build a strong belief system and character of each student so that they can develop their potential and find their life goals. Education in schools is no longer enough to teach students to read, write, and count, then pass exams and later get good jobs. Schools must be able to decide what is right and wrong (Hidayatullah, 2010).

Problems of local culture in the era of globalization suggest that Now, the world is experiencing a 4T Revolution (Technology, Telecommunication, Transportation, Tourism) which has a dominant globalizing force so that boundaries between regions are increasingly blurred and lead to the creation of a global village (Mubah, 2011). On the other hand, if the entry of unfiltered foreign culture is carried out continuously, it does not rule out the possibility that Indonesian culture will become extinct. The shocks of globalization have caused various kinds of crises that damage the image and confidence of the nation (Towaf, 2014). From a social perspective, if students are accustomed to not caring about the environment from an early age, it is feared that it will impact their lives into adulthood.

After the reform era, this nation increasingly likes to kill each other and the development of school bullying cases (Khasbullah, 2013; Muin, 2011). The world of education, which is philosophically viewed and expected as a tool or container to educate and shape the human character to be better (humanization), has begun to shift. This happened one of them due to the inadequacy of the world of education to keep abreast of the times, whereas education should be an 
alternative to overcoming and preventing crises of the nation's character (Manalu, 2014).

Indonesia's education world is only able to produce human graduates with an adequate level of intellectuality (Aunillah, 2011). Many of the school graduates have high grades, are smart, are brilliant, and can solve subject matter very quickly, but unfortunately, not a few of them do not have intelligent behavior and lack a good mental personality. Whereas the purpose of education is to make humans character, noble human beings, humane human beings (Harefa, 2013).

Therefore, a way is needed so that education can show its strength in its participation in improving the nation's identity. One of the methods implemented in recent years is by developing character education. The application of character education for all levels of education. From elementary schools to tertiary institutions was launched by the government since 2010. However, this proclamation is considered to be less successful in delivering generations of the nation into dignified individuals. Therefore a new formula is needed so that the planting of character values can be carried out properly

\section{LITERATURE REVIEW}

\section{Development of Learning Multimedia}

Many experts define what is meant by multi-media according to their respective perspectives. With this difference in perspective, it will increase our understanding of the definition of multi-media. Multi-media is a combination of various media (file formats) in the form of text, images (vectors or bitmaps), graphics, sound, animation, video, interaction, and others that have been packaged into digital files that are used to convey or deliver messages to the public (Munir, 2012). Multi-media is one media that combines all types of media consisting of text, graphics, photos, videos, animations, music, narration, and others (Warsita, 2008).

Dale's Cone of Experience, or called the cone of Dale's experience is commonly used as the grand theory of media usage in the instructional process (Arsyad, 2011). The influence of media in learning can be seen from the level of learning experiences that will be received by students. It gained through real experience and any form of symbols in the environment.

Research findings on learning through image stimulus and word stimulus or visual and verbal conclude that verbal stimulus results in better learning outcomes for tasks of remembering, recognizing, recalling, and linking facts and conditions. Besides, verbal stimuli provide more learning outcomes if learning involves sequential or sequential memories (Saptono, 2011).

This development research expects the learning media produced is good multi-media, which has fulfilled several conditions (attached). Learning media must increase student motivation. The use of media has the aim of motivating students. Besides, the media must also be able to design students to remember what they have learned besides providing new learning stimuli. Good media will also enable students to provide feedback, feedback, and also encourage students to practice correctly.

Multi-media advantages compared to other media are as follows (Warsita, 2008):

1. Flexible both in providing opportunities to choose the contents of each subject presented, as well as variations in their placement to be accessed. Also, the flexibility in its use can be used in class individually or in small groups. Flexible use of time and suitable for everyone.

2. Cell-pacing is to serve the speed of student learning, meaning that the speed of its utilization is highly dependent on the ability and readiness of each student who uses it.

3. Context-rich that is rich in content, meaning that this program has quite a lot of information.

4. Communication interactive is two-way. That is, this program provides opportunities for students to respond.

5. The individual that is serving the speed of individual learning, meaning that this multi-media program has been designed and provided from the beginning to meet students' interests and learning needs.

\section{Character Education}

It has the definition as a deliberate effort to develop good character (good character) based on core virtues (core virtues) objectively both for individuals and society (Saptono, 2011). Character education teaches habitual ways of thinking and behavior that help individuals to live and work together as a family, community, and state and help them to make responsible decisions.

Character definition according to the National Education Center is the innate, heart, soul, and personality, character, behavior, personality, character, character, temperament, character. The characters are personality, behavior, character, 
character, and character. Lickona explained the definition of a good character (good character) as living a life with truth. The truth is related to attitudes toward oneself and others (Akbar \& Al, 2008). People whose behavior is by moral rules are called noble character (Amri \& Al., 2011). Humans with good character are humans who strive to do the best things for God, himself, fellow environment, nation, and country and the world in general by optimizing their potential (knowledge) with emotional awareness and motivation.

According to Samami and Hariyanto, a character is a personality within person-shaped from the heredity factor and surrounding environment which distinguishes from others, and is manifested by others and manifested in attitudes and behaviors in daily life. As a totality of psychological and socio-cultural processes, characters are grouped in: Spiritual and emotional development, intellectual development, physical and kinesthetic development, and physical and kinetic development, and physical and kinetic development. development) (Muclas \& Hariyanto, 2011).

It is understanding how great the contribution of character in coloring the life of a nation cannot be denied that the role of character also has a big role in every dimension of a nation's life. So the role of the character of a nation will determine the quality of national development itself.

Character education is an important aspect of developing effective domains, especially for elementary school-age children. The character education content is applied in learning in elementary schools based on material from the curriculum content standard. Character education is important to be instilled in elementary school-age children because it forms the student's personality so that it has the nation's noble values and can be good citizens. Character education has an important mission in creating students who are not only cognitively smart but also noble characters. Considering all these points the researchers aimed to determine the extent to which the effective use of multi-media in strengthening character education to help students understand the character values contained in the subject matter.

\section{METHODS}

The method used is a literature review of the results of previous studies, which are related to improving character education in schools. A literature review is used in evaluating the quality and new findings of a research result, where the results of this study are in the form of papers from Scientific Journal, Paper from Conference Proceedings), Thesis and Dissertation, and Textbook. The components of the literature review that became the center of attention include a) multi-media development, b) strengthening character education, c) and the relationship between multi-media development and strengthening character education. After conducting a literature review, the researcher then summarizes, analyzes, and synthesizes critically and in-depth from the reviewed papers. The results of the summary, analysis, and synthesis of researchers then create a conceptual design in strengthening character education using multi-media in primary schools.

\section{RESULTS AND DISCUSSION}

Teachers have an important role in developing character education because teachers are agents of reform and have a central role and learning. The teacher must be committed to developing student character based on character values and be able to define in the form of behavior that can be observed in everyday school life. But most importantly, of course, the teacher must also be of good character, bearing in mind the teacher is a role model for students. Professional and character teachers are teachers who can carry out their duties well and internalize positive values to their students (Arifah, 2016).

One of the government's efforts on character education is the Strengthening of Character Education (PPK) which is integrated with the National Movement for Mental Revolution, namely changes in ways of thinking, behaving, and acting for the better (Azwar, 2017). PPK is a continuation of the previous program that provided a solution to the decline in the morale of the nation's children. One of the urgencies of KDP is "21st Century skills needed by students to realize the competitive advantage of the Golden Generation 2045: Character Quality, Basic Literacy, 4C Competence (Critical Thinking an Problem Solving, Creativity, Communication Skills, and Ability to Work Collaboratively)" (Culture, 2017) Through the program, children's abilities both in personality and life skills will develop well along with the development of existing technology and can certainly reduce its adverse effects. Some schools have implemented and implemented the above program according to the needs of the school. By the needs of the school are also interpreted as away. That is adjusted to the needs of the school such as habituation activities and so forth.

Formal education in schools will be very helpful if the school emphasizes education that shapes the character of children. Along with the fading of moral values in today's society, schools must be able to improve the quality of their education and reproduce character education programs. The school (education) is one of the strategic places in the formation of character in addition to the family and community (Hamid, 2017). That is what underlies the need for character education programs in a school, both in the classroom and outside the classroom.

Therefore, it is necessary to plant character education for each school with various activities that can support the planting of good character. One of the activities that can be carried out to strengthen and instill the values of character is 
by making multi-media learning to carry out character education for elementary school students.

The development and formation of student character are increasingly gaining priority in Indonesia with the enactment of Government Regulation no.87 of 2017, on Strengthening Character Education which is an educational movement in schools to strengthen student character through harmonization of heart work (ethics), fitness (aesthetics), thought (literacy), and sports (kinesthetic) with the support of public engagement and cooperation between schools, families, and communities (Article 1 PP no.87 / 2017). Dimensions of processing the character of students in the form of: (1) if the heart is more focused on individuals who have a deep spirituality, (2) if the sense of focus is on individuals who have moral integrity, artistic sense and culture, (3) if the thought focuses on individuals who have superior academically as a result of lifelong learning and learning, (4) sports emphasize healthy individuals who can participate as citizens actively.

For this reason, support is needed from students as well as school infrastructure which is part of the National Revolution of Mental Movement (GNRM). Strengthening character in education refers to five main values which include; (1) religious; (2) nationalists; (3) independence; (4) cooperation; (5) integrity. The five main values of the nation's character

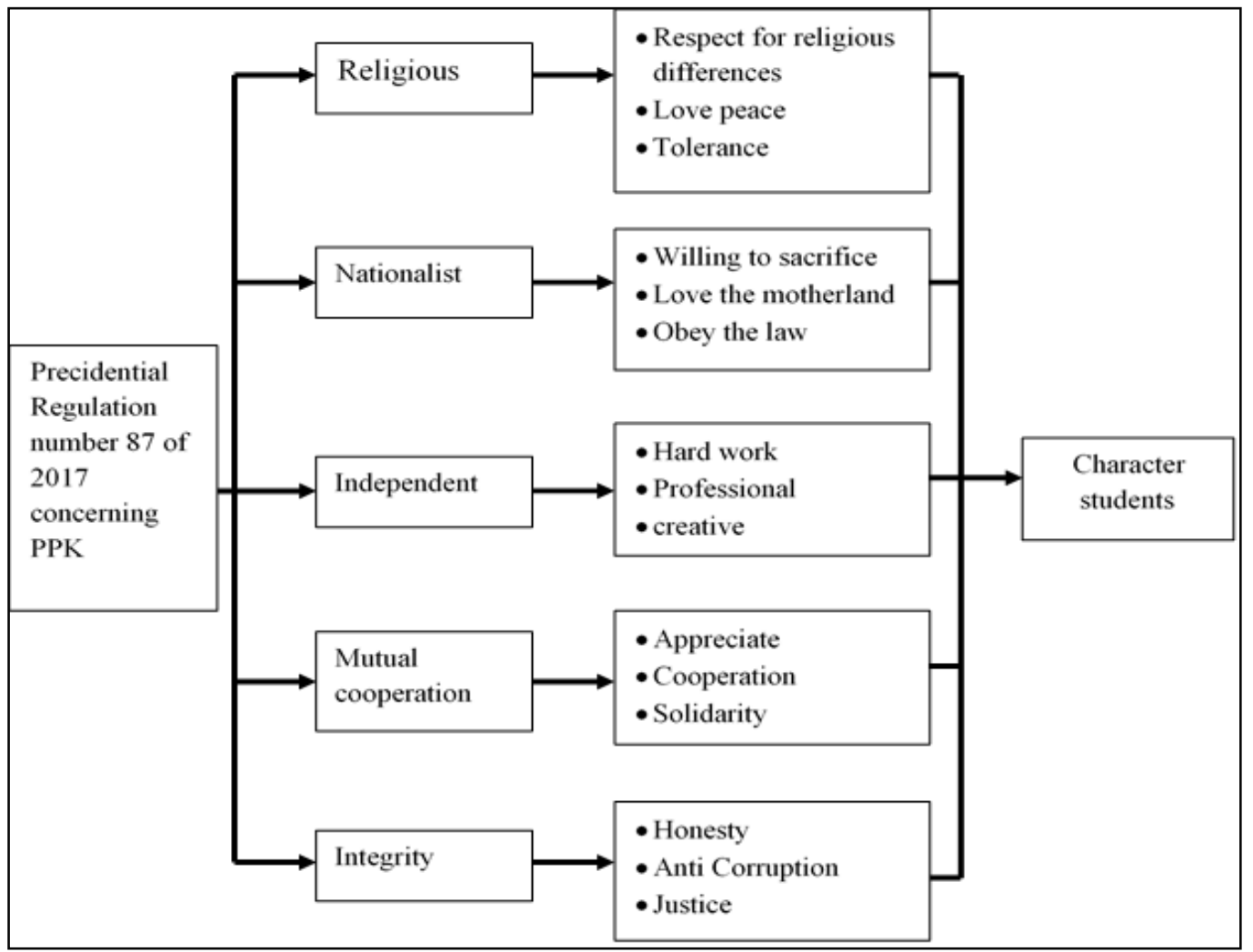

Figure 1: A Conceptual Design in Strengthening Character Education Using Multimedia

Source: (Government Regulation No. 87, 2017)

\section{Religious}

The faith to God is the character belonging to religion as represented by some values such as; tolerant and helpful to others by not considering any background to live together in harmony. There are three aspects of relationships in the religious value covering individual to individual, individual to God, and individual. They reflect on loving, caring, and sharing each other of His creation.

\section{Nationalist}

It consists of loyalty, respect, care, behavior, point of view, political, economic, and socio-cultural aspects that make up the national character values.

\section{Independent}


Independent character values are by not relying on other people or sides by taking maximum efforts to reach the goal effectively and efficiently.

\section{Cooperation}

The character value of working together can be exposed to problem-solving, being helpful, and build meaningful communication.

\section{Integrity}

Saying something and doing the same within the action as to synchronize what spoken and real behavior refer to the character of integrity where loyalty and commitment come in line.

The character of integrity includes an attitude of responsibility as a citizen, actively involved in social life, through consistency of actions and words based on truth. Following is the elaboration of each sub-value of the main value of the nation's character. Implementation of Strengthening Character Education is carried out with the principle of school-based management, which is the responsibility of principals and teachers, as a fulfillment of the workload of teachers and principals (Article 6 paragraph 3,4,5 PP no.87 / 2017). From the description of the experts and also the regulations issued by the government, it is clear that the development of multi-media character education strengthening is very effective to be used to improve the good character of students.

The purpose of the Strengthening Character Education program is to instill the values of the nation's character building to students on a massive and effective basis through educational institutions with priority certain values that will be the focus of learning, understanding, understanding, and practice, so that character education can change behavior, ways of thinking, and ways of acting for all Indonesian people to become better and have integrity.

Strengthening Character Education starts from Early Childhood Education (PAUD), followed by priorities at the level of basic education, namely Elementary Schools and Junior High Schools. The PPK movement at an early age and basic education level will be integrated with the priority values in the National Mental Revolution Movement (GNRM) so that massive and simultaneous changes occur throughout Indonesia.

Based on the results of the literature review, there are five main character values derived from Pancasila, which are the priority for the development of the PPK movement, namely religious, nationalism, integrity, independence, and cooperation. Each value does not stand up and develop individually, but rather interact with each other, develop dynamically, and form personal wholeness.

The religious character values reflect the faith in God Almighty which is manifested in the behavior of carrying out tolerance living among diverse religions and beliefs in the society to live together hand in hand with peace. It can be seen from people's attitudes to live within a heterogeneous environment by considering their social-cultural background to be harmonious in many aspects of life.

The reflection of character which puts nationalism as the priority can be identified from some points covering; promoting public service to personal or individual right, care, loyal, respectful, obey the law and Independent students have a good work ethic, strong, fighting, and full of spirit.

To solve common problems together are done through assistance and build communication with people in need. It is expected that students can show respect for others, can work together, be inclusive, be able to commit to joint decisions, deliberation and consensus, please help, have empathy and a sense of solidarity, anti-discrimination, anti-violence, and voluntary attitudes.

PPK encourages the synergy of three education centers, namely schools, families (parents), and communities (communities) to form an educational ecosystem. According to the Minister of Education and Culture, so far all three seem to be walking on their own, even though synergy can produce something extraordinary. It is hoped that school-based management will strengthen, where schools play a central role, and the environment can be optimized to become learning resources.

The role of the teacher is very important in education and the teacher must be an enlightening figure, who opens nature and mind and soul, cultivates the values of compassion, exemplary values, behavioral values, morality values, diversity values. This is the true character education is the core of real education.

The KDP Implementation Model can be carried out through the Habitual Activity, including Starting the day with the Flag Ceremony (Monday), Apple, singing the Indonesia Raya song, National Song, and praying together. Read non-lesson books about PBP, folklore, 15 minutes before starting learning; before ending learning activities Students do reflection, sing folk songs, and pray together. 
Besides, the implementation of KDP can also be done through Intra-Curricular Activities, namely the integration of character education in Teaching and Learning activities in all subjects. Some positive effects of Strengthening Character Education for elementary school students, one of which students have flexible thinking. By changing the way of learning for elementary school students, students will be taught to have different ways of thinking. For example, instead of asking questions that start with what, who, how, where, they can start asking questions in a way that illustrates critical thinking that is starting with the sentence 'what if?' Besides, students have a good relationship. Because character education covers and teaches the basic values of ethics, elementary school students can implement these teachings in their daily lives. And able to show the emotional, social, and empathy. The value of cooperation to be learned by elementary school students is usually received in vain but with the application of this program, students can relearn the importance of helping one another.

Considering the importance of strengthening character education, learning innovation is needed through the use of multi-media. Multimedia has unique characteristics compared to other learning media. This is a special feature of the multi-media. According to Warsita (Warsita, 2008), the characteristics of multi-media learning are as follows:

1. Having more than one converging media, for example combining several elements.

a. Be interactive, in the sense of having the ability to accommodate user responses.

b. Are independent, in the sense of providing convenience and completeness of content so that users can use without the guidance of others.

c. It is programmed that contains learning materials that are arranged and provide a lot of information.

In line with this opinion Daryanto (Daryanto, 2010) multi-media has the following characteristics:

a. Having more than one converging media, which combines several media elements, such as audio, visual, and others?

b. Be interactive, that is to say, multi-media can greet users.

c. Be independent, meaning that multi-media provides convenience and completeness of content so that users can use it without the guidance of others.

Multimedia has different design principles compared to other learning media. With the existence of these principles, it can be used as guidelines for making good multi-media and can be applied in everyday life. The following are the principles of multi-media design, according to Mayer (Mayer, 2009) in the research he has examined, namely:

1. Multimedia Principles. On this principle, students can learn better through various types of media (images, sound, text, video, etc.), not just words.

2. Principles of Space Closeness. On this principle, students can learn properly related to images and words given or presented in the same space, compared if the words and pictures are located far apart, for example, between words and images that are interrelated with different pages.

3. Principles of Time Closeness. In this principle, it is the same as the previous principle about the proximity of space. The principle of this time closeness, students will learn better when words and images are displayed at the same time rather than alternately.

4. Principle of Coherence. Under this principle, students can learn better when words, pictures, and sounds are discarded rather than inserted.

5. Principle of Modalities. Under this principle, students have chances to study animation and narration better.

6. Redundancy Principle. On this principle, students can get deeper into learning about animation and narration.

7. Individual Differences Principle. On this principle, multi-media design and its effect can have a strong influence on students with low knowledge.

This shows that multi-media have binding rules in making multi-media designs. This certainly will be an added value of multi-media itself, considering that in its development, it must be by the principles/rules that exist. Multi-media learning is useful in several situations. Based on this, in the instructional process, multi-media can be functioned in three ways namely; learning source, interactive media, and learning assistance.

Azhar Arsyad (Arsyad, 2011) states that multi-media provides practical benefits in the instructional process mentioned below:

1. Multi-media learning can increase learning achievement and give access to information. 
2. Learning media supports students to have independent learning with positive motivation.

3. Media in learning can solve the problems related to time, area, and senses.

4. Learning media can facilitate a common experience to students related to activities surrounding and allowing direct interaction with the teacher, the community, and the environment, for example through field trips, visits to museums, or zoos.

In line with the opinion above, Daryanto (Daryanto, 2010) states that multi-media provides benefits for teachers and students, among others, as follows:

1. The learning process becomes more interesting for students. This is because in multi-media there are so many features that are so many and diverse that they will be able to attract students' attention.

2. The existence of interactive in learning. This is because in multi-media it allows feedback with students, so it is possible to have a positive interaction between multi-media and its users.

3. Learning time to be efficient. This is because multi-media can be made according to certain time constraints, so as not to allow excessive material delivery. So that the material does not overlap in the delivery. Another thing that makes time efficient is because multi-media can be used anywhere and anytime.

4. It can improve the quality of learning. In multi-media, many features can enrich learning so that it can complement the subject matter delivered by the teacher at school.

5. Increase the attractiveness of students in learning. This is because in the multi-media available a variety of material and appearance so that it will be able to attract students' attention in carrying out learning.

According to Muhammad Abrori (Abrori, 2009) Flash is a smart tool for creating character animations. The user interface (user interface) of this tool is easier to understand than other similar tools. Flash is software that can draw as well as animate and easy to learn. Flash is not only used in making animation but in this day and age, flash is also widely used for other purposes such as in making games, presentations, building the web, learning animations, even in filmmaking. Flash is the right tool for creating animations in cartoon format. With flash, cartoons can be distributed quickly, cheaply, and most easily because users can play files using various types of hardware.

It is undeniable that flash is a 2D animation program that is very reliable 2D. No wonder if, in its development, Flash made a lot of improvements in each version. Flash, which used to belong to Macromedia, has now joined Adobe. Amazingly, with Adobe Flash we can create a variety of 2D animation applications ranging from cartoon animation, interactive animation, games, company profiles, presentations, video clips, movies, web animations, and other animation applications according to our needs (Madcoms, 2008).

According to Madcoms (Madcoms, 2008), the advantages and sophistication of Flash in creating and processing 2D animation, namely:

1. Creating interactive tools.

2. Producing color mixture.

3. Making animation shifting.

4. Motion on an animated predetermined path.

5. Resulted in various file forms extensions.

6. Processing animations from Bitmap objects.

7. Flash-based vector animation programs have flexibility in making vector objects.

8. Integrated with Adobe Photoshop and Illustrator.

These strengths are what make the researchers interested in developing learning media. The learning media include interactive multi-media types. These strengths are what make the researchers interested in developing multi-media learning. Multi-media learning, including interactive multi-media types. This interactive multi-media contains material in class IV in semester II Theme 1 The Beauty of Togetherness Subtema 2 Togetherness in Diversity.

Based on the Act states that education functions to shape character. This character is called character. Character education has an important role in moral formation. According to Lickona, characters are related to moral concepts, moral attitudes, and moral behavior (Isnaini, 2016). Based on these three components, it can be concluded that good character is supported by the knowledge of goodness, the desire to do good and to do good deeds. Strengthening Character Education is a continuation and revitalization of the national movement for character education that began in 2010 . 
The system where values of character to be included in the school members across aspects such as awareness and knowledge is called as character education. It consists of developing positive attitudes, essential thought patterns, normative commitment, and components of ability based on IESQ (Manullang, 2013). The development of national character is very important because it is related to the process of fostering, improving, and inheriting citizens about the concepts of behavior and noble values of Indonesian culture imbued by Pancasila and the 1945 Law (Jonah, 2013). Therefore, the nature of character education in the context of education in Indonesia is the education of noble values that originate from the culture of the Indonesian people themselves to foster the personality of the nation's next generation.

Education is not enough to stop at providing the most up-to-date knowledge, but also must be able to form and build a strong belief system and character of each student so that they can develop their potential and find their life goals. Education in schools is no longer enough just to teach students to read, write, and count, then pass exams and later get good jobs. Schools must be able to decide what is right and wrong (Hidayatullah, 2010).

To overcome this all education is needed that can develop individual potential while forming a generation of moral and noble character. In short, the purpose of education must lead to the development of various Indonesian human characters, not merely academic education (Law of the Republic of Indonesia Number 20 the Year 2003 concerning the National Education System, 2003).

Therefore, the strengthening of character education in the current context is in line with the effort to eradicate the moral crisis in Indonesia (Santosa, 2014). It teaches on perspective and behavior that help individuals to live as good students in their daily lives and can make responsible decisions. In other words, character education teaches students to think smartly to be able to overcome various kinds of existing problems, increase the ability to mingle with others while maintaining the national identity and culture.

Therefore, it is necessary to plant character education for each school with various activities that can support the planting of good character. One of the activities that can be carried out to strengthen and instill the values of character is by making multi-media learning to carry out character education for elementary school students.

Efforts to improve character education occupy a fundamental and strategic position when the government launches a national character revolution as outlined in Nawacita (Nawacita 8), fostered the National Movement for Mental Revolution and published the 2014/2019 RPJMN based on Nawacita. As an embodiment of the National Mental Revolution Movement as well as an integral part of Nawacita, efforts to strengthen character education place character as the deepest dimension or as the core of national education. Furthermore, efforts to strengthen character education in practice require the integration, deepening, expanding, and at the same time aligning various programs and character education activities that have been carried out until now, so that the goals and functions of character education itself can be achieved properly.

From the description of the experts and also the regulations issued by the government, it is clear that the development of multi-media character education strengthening is very effective to be used to improve the good character of students.

Hurlock (Hurlock, 1993) divides child development into five periods, namely:

1. Pre-birth period with the fast development in psychologically within the body in one.

2. The neonatal period where babies make adaptations to the environment outside them other's womb that is completely new to the baby.

3. The baby is a baby who has the motivation to be independent and muscle control by age two weeks to two years.

4. Early and late childhood by aged two to six years old and to be adjusted socially at the end of childhood age by six to thirteen years old.

5. The range of age from 11 to 16 years is called puberty. This period includes a san overlapping period because it is two years late childhood and two years early of adolescence into adult physically.

Piaget divides these stages of cognitive development into four stages namely, the sensorimotor stage, the preoperational stage, the concrete operational stage, and the formal operational stage. According to Shaffer \& Kipp in Setyawan \& Mustadi (Setyawan, W., \& Mustadi, 2015), states that Piaget's theory of cognitive development at the age of class IV students are at the concrete operations stage (concrete operations) where students get and use all their knowledge with something logical or reasonable. The logical thing can be obtained through concrete and meaningful activities.

However, logical thinking with all the elements above is still limited to be applied to concrete objects; the thought has not been applied to verbal sentences, hypotheses, and abstracts. So, children at this stage still have difficulty to solve problems that have too many aspects and variables. He also still cannot solve abstract problems. That is why children at this age still need guidance and direction from parents and teachers. 
AccordingtoSuryobroto in Djamarah (Djamarah, 2011), some of the characteristics of children during high class in elementary school are as follows.

1. There is an interest in concrete practical daily life.

2. Very realistic, have high curiosity and want to learn.

3. Towards the end of this period, children have an interest in several things and special subjects.

4. Until about 11 years so far, children need a teacher or other adults.

5. Children at this time like to form peer groups.

Based on the theoretical basis and the results of relevant development research as described previously, the researcher considers the need to develop multi-media that can be used to support the integrative thematic learning process in the 2013 Curriculum based on Scientific Approach. In developing these multi-media, researchers pay attention to the material to be studied, the characteristics of students, the quality of content, and student attractiveness. This is an effort to produce learning media in the form of appropriate learning multi-media,

This interactive multi-media is structured to answer one of the teacher's needs in applying the concept of integrative thematic learning. This interactive multi-media that was developed will package the material on the theme of Togetherness in Diversity, by integrating about seven subjects and presenting them into six times of learning.

In making Pancasila-based character education multi-media there are several values and equipment that support the course of making this multi-media. The elements that become the contents of multi-media production include subject matter, Pancasila character values, games (games), and evaluations (questions). The elements of subject matter include PPKn, Mathematics, Indonesian Language, Natural Sciences, Social Sciences, PJOK, and SBdP. Pancasila's character values include the principles of the God of YME, Humanity that is and Adjacent, Indonesian Unity, Society Led by Wisdom Wisdom in Representative Consultation, and Social Justice for All Indonesians. Components of the game include matchmaking, choosing, differentiating, and searching for tracks. Evaluation involves working on multiple-choice test questions.

\section{CONCLUSION}

By developing multi-media strengthening character education (KDP) in this elementary school will be able to form individuals who have the character to be the golden generation of Indonesia in 2045 with 21 st-century skills. With the following characteristics: Individuals who have academic excellence as a result of lifelong learning and learning (Thinking); Individuals who have deep spirituality, faith and piety; Individuals who have moral integrity, a sense of art and culture (if the taste and intention); Individuals who are healthy and able to actively participate as citizens (Sports).By the use of multi-media included in the instructional process, it opens more chances and possibilities for the teachers to direct students' personalities into national character building referring to the moral values. It also responds to the necessities of the fast-growing technology to be applied in more effective ways especially in the field of education.

\section{LIMITATION AND STUDY FORWARD}

The scope area in this study is focused on the literature through a systematic literature review where the findings resulted from the previous study were analyzed and leading for conclusions related to multi-media and students' character. It is highly recommended for future research to use the findings in this research as the basis to conduct field study regarding the effectiveness of using multi-media to form students' personalities seen from social-cultural aspects as it has not been exposed yet.

\section{ACKNOWLEDGMENT}

Wholeheartedly thankfulness is dedicated to all authors as contributed significantly to finish this paper. The second and five authors for the insight to analyze and interpret the data, the third author for his revision on the starting draft on the theoretical construction and summing up the conclusion, and the fourth author in presenting the descriptive analysis for each journal as the source of study are truly supporting actions to make it through.

\section{REFERENCES}

1. Abrori, M. (2009). Solusi Instan Animasi Karakter Dengan Adobe Flash. Yogyakarta: Andi.

2. Akbar, S., \& Al, E. (2008). Best Practice Character Education. Malang: Malang State University.

3. Amri, S., \& Al., E. (2011). Implementation of Character Education in Learning. Jakarta: PT Prestasi Pustakarya.

4. Arifah, F. N. (2016). Become an Exemplary, Creative, Inspirational, Motivative, and Professional Teacher. Yogyakarta: Araska.

5. Arsyad, A. (2011). Instructional Media. Jakarta: Rajawali Press.

6. Aunillah, N. I. (2011). Guide to Implementing Character Education in Schools. Yogyakarta: Like Publisher. 
7. Azwar, K. (2017). FDS Program Encourages Character Education.

8. Culture, M. of E. and. (2017). Understanding, Basic Concepts, and Benefits of Strengthening Character Education and Important Things Related to PPK that Teachers Must Obtain.

9. Daryanto. (2010). Media pembelajaran peranannya sangat penting dalam mencapai tujuan pembelajaran. Yogyakarta: Gava Media.

10. Djamarah, S. B. (2011). Psikologi belajar. Jakarta: Rineka Cipta.

11. Hamid, A. (2017). Pesantren-Based Character Education: Students and Santri in the Era of IT \& Cyber Culture. Surabaya: IMTIYAZ.

12. Harefa, A. (2013). Picking Luck. Jakarta: PT Elex Media Komputindo.

13. Hidayatullah, M. F. (2010). True Teachers: Building People with Strong and Smart Characters. Surakarta: Yuma Pustaka.

14. Hurlock, E. B. (1993). Child Development (Terjemahan: Tjandrasa dan Zarkasih). Jakarta: PT. Gelora Aksara Pratama.

15. Isnaini, R. L. (2016). Strengthening Student Character Education Through Islamic Guidance and Counseling Management. Manageria. Journal of Islamic Education Management, 1(1), 35-52. https://doi.org/10.14421/manageria.2016.11-03

16. Jonah, R. (2013). Transforming Local Cultural Values as Efforts to Build a Nation's Character. Journal of UPI Education Research, 13(1), 67-79.

17. Khasbullah, M. N. (2013). The Concept of Character Education According to Ibn Maskawih: Its Relevance to the Implementation of Culture and Character Education of the Ministry of Education and Culture. STAIN Kediri.

18. Law of the Republic of Indonesia Number 20 the Year 2003. (2003). concerning the National Education System.

19. Madcoms. (2008). Panduan Lengkap Adobe Flash CS3 Profesional. Yogyakarta: Andi.

20. Manalu, J. M. H. (2014). Character Education on Student Behavior Formation (Case Study of Character Education Process in HMJ Sociologist, Mulaarman University, East Kalimantan). Psychology Journal, 2(4), $26-38$.

21. Manullang, B. (2013). Grand Design of Gold Generation Character Education 2045. Journal of Character Education, 3(1), 1-14.

22. Mayer, R. E. (2009). Multimedia learning prinsip-prinsip dan aplikasi. (Terjemahan Teguh Wahyu Utomo). New York: Cambridge University Press. https://doi.org/10.1017/CBO9780511811678

23. Muin, F. (2011). Character Education: Theoretical Construction and Practice. Yogyakarta: Ar-Ruzz Media.

24. Mubah, A. S. (2011). Strategy to Increase the Endurance of Local Culture in Facing Globalization Flows. Journal of Airlangga University, 24(4), 302-308.

25. Muclas, S., \& Hariyanto. (2011). Character Education Concepts and Models. Bandung: PT Remaja Rosdakarya.

26. Munir. (2012). Multi-media concepts \& applications in education. Bandung: Alfabeta.

27. Santosa, A. W. (2014). Karakter Education Implementation in Building Student Independence and Discipline in MTsN Kanigoro Kras, Kediri Regency. Journal of Religia Didactic, 2(1), 21-38.

28. Saptono. (2011). Dimensions of Character Education. Jakarta: Essence.

29. Setyawan, W., \& Mustadi, A. (2015). Pengembangan SSP Tematik-Integratif Untuk Membangun Karakter Disiplin Dan Kreatif siswa Kelas I SD. Jurnal Prima Edukasia, 3(1), 108-119. https://doi.org/10.21831/jpe.v3i2.7222

30. Towaf, S. M. (2014). Character Education in Social Sciences Subjects. Journal of Educational Sciences, 20(1), $75-85$.

31. Warsita, B. (2008). Foundation learning technology and its application. Jakarta: Rineka Cipta. 